\title{
Studia
}

SYNCHRONICZNE I DIACHRONICZNE ASPEKTY BADAŃ POLSZCZYZNY

www.wnus.edu.pl/sj | DOI: 10.18276/sj.2020.19-11 | 163-180

\section{MAREK KASZEWSKI}

ORCID: 0000-0001-5871-7440

Akademia Pomorska w Słupsku

kaszewski@o2.pl

\section{O interiekcjach kaszubskich w perspektywie leksykograficznej}

\section{Słowa kluczowe}

interiekcje, tożsamość kaszubska, słowniki polskie i kaszubskie, definiowanie, pochodzenie kaszubskich wykrzykników

Keywords

interjection, Kashubian identity, Polish and Kashubian dictionaries, defining, origin of Kashubian interjections

Interiekcje w dziejach lingwistyki z jednej strony jawią się jako istotny kłopot - zarówno pod względem klasyfikacyjno-opisowo-funkcjonalnym (ich miejsce w systemie języka, typologia ze względu na funkcję, budowę czy pochodzenie), jak i materiałowym (wybór właściwych źródeł dla ekscerpcji) oraz leksykograficznym (repertuar jednostek, ich kształt formalny, definiowanie). Stanowi owa klasa wielkie wyzwanie dla współczesnej lingwistyki, o czym świadczy często traktowanie ich jako redundantnego, kłopotliwego w analizie elementu języka, pozostającego na marginesie głównych dociekań badaczy systemów: zarówno indo-, jak i nieindoeuropejskich. Te wątki i podobne komentarze przewijają się w pracach kolejnych badaczy omawianej kategorii gramatycznej, mimo że w ostatnich kilkunastu latach można zaobserwować wzrost zainteresowania problematyką, szczególnie w aspekcie konfrontatywnym i translatologicznym. Mimo to ów niezwykle zróżnicowany wewnętrznie zbiór jednostek doczekał się stosunkowo licznych opracowań, uwypuklających 
różne aspekty zbioru interiekcji w rozmaitych językach, by wspomnieć w tym miejscu tylko o kilku monografiach przedmiotowych, np. autorstwa Marceliny Świątkowskiej, Elżbiety Orwińskiej-Róziczki, Ewy Siatkowskiej czy Sybilli Daković, obok nich często w literaturze przywoływanych propozycjach klasyfikacyjnych Macieja Grochowskiego, Leokadii Styrcz-Przebindy lub nowatorskich ujęć Moniki Krzempek, dotyczących interpretowania interiekcji w perspektywie kognitywnej. Problem ujmowany jest w różnojęzycznych opracowaniach i kompendiach lingwistycznych z uwzględnieniem rozmaitych aspektów interiekcji: ich właściwości syntaktyczno-predykatywnych (ewentualnie fleksyjnych - czy też de facto braku takich właściwości), cech semantyczno-funkcjonalnych, charakterystyki fonetyczno-akustycznej (ewentualnie słowotwórczej). Z uwag o charakterze generalizującym należy przytoczyć sugestię M. Świątkowskiej, kluczową dla koncepcji niniejszej badaczki, przewijającą się w różnych jej tekstach, w tym w monografii zatytułowanej Entre dire et faire. De l'interjection. Autorka stwierdza mianowicie, że interiekcje stanowią:

[...] z punktu widzenia morfologii le ks e my n i e p odziel ne [podkr. - M.K.], nieodmienne, nie tworzące klasy zamkniętej; z punktu widzenia składni to wyrazy-zdania lub równoważniki zdań, które albo pełnią funkcje członu zależnego w zdaniu, albo częściej są jednostką niezależną; z semantycznego punktu widzenia posiadają sens, choć jest on trudny do określenia, ponieważ zależy od kontekstu, sytuacji, intonacji, gestykulacji i mimiki ${ }^{1}$.

Podobnie ujmuje problematykę interiekcji S. Daković, która stwierdza:

Przyczyn braku zainteresowania interiekcjami należy szukać w trudnościach, jakie sprawia nie tylko ich opis, ale także samo zgromadzenie inwentarza stanowiącego podstawę badań. Ma to związek z naturą interiekcji, która sytuuje je na pograniczu języka i pozajęzykowych środków wyrazu, a także z tym, że funkcjonują one głównie w języku mówionym. Z kwestią interiekcji wiąże się również wiele kontrowersji, począwszy od zasad wyodrębniania tych leksemów, po zagadnienie posiadania przez nie znaczenia. Ciągle jeszcze widoczne są też problemy z leksykograficznym opisem interiekcji, co jest związane z niewypracowaniem metod ich opisu. [...]. Badanie interiekcji w aspekcie porównawczym pomogłoby odpowiedzieć na wiele pytań dotyczących nie tylko natury samych leksemów, ale także aspektów związanych z początkami mowy czy istotą ludzkiej komunikacji i ekspresji werbalnej².

Interiekcje potraktować można w świetle historii badań teoretycznojęzykowych jako wręcz esencję języka czy źródło ludzkiej mowy in genere - patrz uwagi Wilhelma

\footnotetext{
1 Marcelina Świątkowska, „Quelques considérations sur la nature de l'interjection”, Prace Językoznawcze 63 (1979), 49.

2 Sybilla Daković, Interiekcje w języku polskim, serbskim, chorwackim i rosyjskim. Opis i konfrontacja (Wrocław: Wydawnictwo Uniwersytetu Wrocławskiego, 2006), 9.
} 
Wundta w jego słynnej Völkerpsychologie, a także sugestie metodologiczne Hermanna Paula (Prinzipien der Sprachgeschichte) czy Ernsta Schwentnera, który rozwijał koncepcję Wundta (Die primären Interiectionen in der indogermanischen Sprachen). Znamienne, że czytanym i analizowanym po ok. stu latach propozycjom interpretowania klasy wykrzykników przez wymienionych badaczy - mimo że stanowią one w pewnej mierze historyczne zaświadczenie efektownych spekulacji o genezie języków in genere ${ }^{3}$ - i dzisiaj nie można odmówić metodologicznej i rozpatrywanej z logicznego punktu widzenia wiarygodności (w tym miejscu znajdują się też zagadnienia domniemanej binarnej - referencjalnej i symbolicznej - funkcji interiekcji), a odwołania do tych koncepcji odnajdujemy w pracach poświęconych choćby wykrzyknikom angielskim, francuskim, szwedzkim czy włoskim. Zaproponowane przez wymienionych naukowców propozycje klasyfikacyjne wzmiankowanych części mowy były i są całkowicie świadomie bądź jedynie intuicyjnie powielane, przywoływane, kontynuowane i rozwijane w ciągu kolejnych dziesięcioleci przez badaczy omawianej klasy jednostek komunikacji i ekspresji lub też pojawiają się poniekąd „przy okazji” - na marginesie zupełnie innych rozważań, obejmujących studia nad podsystemami słowotwórczymi czy składniowymi języków. Największe zainteresowanie i zarazem największe kontrowersje budzą w opracowaniach językoznawczych interiekcje onomatopeiczne oraz adanimalne, czyli dozwierzęce, rozumiane jako ,zawołania na zwierzęta, jakie przekazują rozkazy, na które zwierzę reaguje odruchowo określonym zachowaniem - z racji swej odmienności biologicznej nigdy nie może reagować słownie. Są to znaki jednokierunkowe"^ wraz z odzwierzęcymi, o znacznej części których można mówić w aspekcie iloczynu lub nawet inkluzji zbiorów (wykrzykniki dozwierzęce albo odzwierzęce stanowią w domniemaniu lingwistów onomatopeje, a idąc za propozycjami Wundta, sugerującego dychotomiczne funkcje tej klasy reprezentowanej przez jednostki prymarne i sekundarne, jako bezpośrednie naśladownictwo dźwięków naturalnych [obok niego symbolizowanie jakiejś treści] - należałoby interiekcje adanimalne i odzwierzęce zaklasyfikować do tej pierwszej grupy. Korespondowałoby to z ustaleniami niektórych slawistów, doszukujących się osobliwości w brzmieniu głosek stanowiących budulec takiego typu interiekcji jako dźwięków nieartykułowanych, niewystępujących w językach, a bardzo dokładnie imitujących mowę zwierząt ${ }^{5}$ ). Specyficzne właściwości onomatopei komplikują jeszcze kwestie jej reprezentacji w zbiorze interiekcji - Ewa Siatkowska np. uważa, że interiekcyjnym tworom onomatopeicznym przysługuje w ogóle odrębny status poza zbiorem wykrzykników ze względu na ich specyficzny status ontologiczny (semiotyka, właściwości

\footnotetext{
3 Zob. też: Marcelina Świątkowska, A może na początku byt wykrzyknik?, w: Między oryginałem a przekładem, seria: Na początku byt przekład, t. 5, red. Maria Filipowicz-Rudek i in. (Kraków 1999), 277-286.

4 Ewa Siatkowska, Zachodniostowiańskie zawołania na zwierzęta (Warszawa: Wydawnictwo Uniwersytetu Warszawskiego, 1976), 169.

5 Anatol Mirowicz, Przegląd i charakterystyka części mowy w języku rosyjskim (Warszawa: Państwowe Wydawnictwo Naukowe, 1967).
} 
znaczeniowo-funkcyjne, fonetyczne i morfologiczne, a także rola pełniona w komunikacji ${ }^{6}$ ). Wskazane względy sprawiają, że problemem dla badacza staje się sama ekscerpcja materiału na potrzeby analizy - wszak nawet współczesne, zaawansowane pod względem metod leksykograficznych, słowniki nie są konsekwentne pod względem metody opisu (o czym wzmiankowała w swej monografii S. Daković), a repertuar rejestrowanych jednostek nie odpowiada rzeczywistości językowej i praktyce komunikacyjnej:

Pod powszechnie przyjętą definicją, mówiącą, że interiekcje są wyrazami uczuć i woli mówiącego umieszczana jest szeroka skala elementów, od głosów nieartykułowanych począwszy, przez przekleństwa, na zdaniach wykrzyknikowych skończywszy. Niektórzy badacze zakreślają szerokie ramy interiekcji, tworząc z nich klasę bardzo pojemną, inni są skłonni ją zawężać [...]. Jednocześnie definicje nie proponują wyraźnych zasad wyodrębniających interiekcje lub nie przestrzegają zakreślanych przez siebie ram klasyfikacji, czego skutkiem jest spora dowolność w wyznaczaniu granic interiekcji. Częstym wypadkiem jest też przypisywanie przez jednego autora określonych leksemów interiekcji, podczas gdy u drugiego znajdują one miejsce w innej grupie?

W niniejszym, syntetycznym opracowaniu wyznacza się relatywnie wąskie rozumienie interiekcji (bez uwzględniania dopowiedzeń), stanowiących część mowy (kategorię gramatyczną), która może, ale nie musi być pozbawiona właściwości fleksyjnych, która może stanowić równocześnie leksem i zdanie, składa się z pojedynczego elementu wokalicznego, sylab lub morfemów, jakie w akcie komunikacji mogą być dowolnie reiterowane, a znaczenie tych jednostek najczęściej konstytuuje się dopiero w kontekście; takie formy często wyrażają różne stany emocjonalne, ale nie jest to ich cecha obligatoryjna.

Część kaszubskich jednostek wykrzyknikowych była już przywoływana i omawiana przez E. Siatkowską w monografii zachodniosłowiańskich zawołań na zwierzęta, jednak materiał badany przez autorkę pochodził z Atlasu Językowego Kaszubszczyzny (dalej AJK), o którego de facto historycznym już charakterze po latach sama jego współtwórczyni Hanna Popowska-Taborska napisała: „Materiał [...] reprezentuje stan archaiczny, nie istniejący już w wielu ankietowanych wsiach. Liczne wyrazy i formacje, znane w latach 50. tylko najstarszemu pokoleniu, zginęły bezpowrotnie wraz ze śmiercią informatorów atlasu"8. Traktowany w tym duchu, AJK może dostarczać interesujących faktów dotyczących wygasania słownictwa w połowie XX stulecia i powinien stanowić pomocnicze źródło ekscerpcji materiału przede wszystkim dla historyków języka. W obliczu braku korpusów językowych dla kaszubszczyzny (takich, jakimi dysponujemy choćby dla polszczyzny

\footnotetext{
6 Ewa Siatkowska, „Wyrazy dźwiękonaśladowcze a wykrzykniki (studium porównawcze na materiale czeskim i polskim)", Poradnik Językowy 3 (1977): 100.

7 Daković, Interiekcje w języku polskim, 28-29.

8 Hanna Popowska-Taborska, Szkice z kaszubszczyzny (Gdańsk: Muzeum Piśmiennictwa i Muzyki Kaszubsko-Pomorskiej w Wejherowie i Towarzystwo Przyjaciół Ziemi Wejherowskiej, 1987), 45.
} 
historycznej i współczesnej, typu Korba, F19, NKJP czy Fotokorpus) na potrzeby badań nad interiekcjami, jako sferą języka wymagającą pogłębionego komentarza filologicznego, zasadna wydaje się ekscerpcja źródeł leksykograficznych, bo to one właśnie - obok innych źródeł metajęzykowych - w obrębie mikrostruktury słownikowej, informacji gramatycznej, kwalifikowania i definiowania haseł pokazują sposób funkcjonowania interiekcji zarówno w przestrzeni semiotyczno-symbolicznej (szeroko rozumianej semiosferze), jak i w świadomości lingwistycznej kaszubskich leksykografów-autochtonów.

W niniejszym szkicu wyzyskano materiał z trzech słowników kaszubskich, spośród których pierwszy (najwcześniejszy chronologicznie) - autorstwa Stefana Ramułta - należy potraktować jako źródło historyczne, a pozostałe dwa (J. Trepczyka i B. Sychty) jako rezerwuar słownictwa potencjalnie żywego w kaszubszczyźnie. Należy w tym miejscu podkreślić, że nie są to kompendia w równym stopniu wiarygodne, jak zresztą zgodnie stwierdzają kaszubscy lingwiści, badacze leksykografii tego języka, ale też sami autochtoni, bez przygotowania filologicznego. Wybór podstawy materiałowej dla ekscerpcji wykrzykników kaszubskich ma szczególną wagę ze względu na labilność omawianej klasy jednostek, nieostrość jej konturów.

Charakterystyczna dla kaszubskiej leksykografii, traktowanej w niektórych przypadkach jako zaangażowana ideowo praktyka podtrzymywania i budowania lokalnej tożsamości zbiorowej w oparciu m.in. o podkreślanie odrębności językowej niż teoria tworzenia słowników narodowych (etnolektalnych) - vide dzieło Jana Trepczyka - jest kwestia tworzenia nowych wyrazów, które w istocie nigdy w tym języku się nie pojawiły. Zjawisko, o którym mowa, znamienne przecież także dla historycznej leksykografii polskojęzycznej, ma kilka wyrazistych przyczyn, przynosi też poważne konsekwencje w kwestii wiarygodności materiału językowego ekscerpowanego na potrzeby badań filologicznych. Do czynników warunkujących tworzenie „sztucznych” wyrazów kaszubskich w obrębie dzieł leksykograficznych można zaliczyć przynajmniej kilka przyczyn:

- wyrażanie indywidualnych skłonności autorów, poczucie realizacji misji poprzez wkład w budowanie czy utrwalanie kaszubszczyzny literackiej, ale i jej subkodów funkcjonalnych, rywalizacja z poprzednikami, uzupełnianie domniemanych ,braków” we wcześniejszych słownikach;

- wskrzeszanie słów staropolskich bądź budowanie ich replik;

- tendencja do słowotwórstwa potencjalnego, polegającego na wypełnianiu paradygmatów słowotwórczych, wakujących miejsc w obrębie gniazd (a w przypadku tych dzieł - łańcuchów słowotwórczych);

- wypełnianie nisz językowych wynikających z pojawiania się nowych desygnatów, dla których brak jeszcze kaszubskiego nazewnictwa;

- identyfikacja z postulatami programowymi grup ideowych (np. Zrzeszincë), oczyszczanie języka z polonizmów, germanizmów bądź internacjonalizmów.

Należy w tym miejscu podkreślić, że problematyka leksykografii kaszubskiej-zarówno dawniejszej, jak i współczesnej - jest bardzo dobrze opisana w naukowej oraz popularnej 
literaturze przedmiotu (szczególnie w licznych tekstach H. Popowskiej-Taborskiej, także J. Tredera i E. Brezy); trzeba jednak nadmienić, że owe opisy i oceny poszczególnych leksykonów dokonywane są przez samych Kaszubów bądź osoby identyfikujące się z Kaszubami i w związku z tym - postrzegane z kaszubskiej perspektywy tożsamościowej.

Na potrzeby niniejszego tekstu ekscerpcji poddano następujące źródła przekładowe:

- Stefan Ramułt, Słownik języka kaszubskiego, czyli pomorskiego (1893), ok. 14000 wyrazów;

- Bernard Sychta, Słownik gwar kaszubskich (1967-1970), ok. 61000 wyrazów.

- Jan Trepczyk, Słownik polsko-kaszubski (1994), ok. 60000 wyrazów.

Ograniczona jest wartość (i wiarygodność) źródłowa słowników Ramułta i Trepczyka - pierwszy z nich ma znaczną rangę historyczną, ale dostarcza relatywnie małej liczby haseł, spośród których pewną część stanowią neologizmy autora; z kolei twórca drugiego z wymienionych źródeł nie dysponował przygotowaniem filologicznym, a w kwestii reprezentacji leksykalnej uważa się, że przynajmniej połowa haseł została w istocie przez Trepczyka wymyślona. Trzeci z ekscerpowanych słowników na stałe wszedł do kanonu źródeł nie tylko dla językoznawców i literaturoznawców, ale także dla etnografów, etnologów, antropologów kultury itd.:

Słownik B. Sychty w naukowym świecie slawistycznym uważany jest za jedno z najlepszych dzieł tego rodzaju, wykorzystywany jest jako podstawowe źródło w dociekaniach nad kaszubszczyzną, niezbędne również w wypadku szerszych slawistycznych studiów komparatystycznych. Do zbioru tego sięgają etymolodzy poszczególnych języków słowiańskich, szereg bowiem słów i form tu cytowanych rzuca nowe światło na interpretację leksyki słowiańskiej9

W kontekście powyższych uwag dzieło Bernarda Sychty winno jawić się jako podstawowe źródło ekscerpcji także materiału interiekcyjnego. Jeśli jednak skoncentrować się w tym miejscu na tożsamościowym kryterium traktowania języka jako elementu konstytuującego poczucie odrębności, okaże się, że w świetle zgromadzonego materiału słownikowego kaszubskie interiekcje stanowią istotny komponent językowej tożsamości kaszubskiej regionalnej i wspólnotowej, ale są przynajmniej powodem do dumy, wartej zaakcentowania w opracowaniach leksykograficznych. Okazuje się bowiem, iż interiekcje we wszystkich analizowanych słownikach kaszubskich stanowią istotną grupę słownictwa, a w przypadku dzieła B. Sychty jest to reprezentacja wręcz ogromna, którą w zasadzie dałoby się bez problemu wyodrębnić jako osobny wręcz słownik (na potrzeby niniejszego szkicu wyekscerpowano materiał jedynie $\mathrm{z}$ dwóch tomów, gdzie odnaleziono ponad 70 interesujących nas jednostek).

9 Hanna Popowska-Taborska, „O Słowniku kaszubskim Bernarda Sychty”, Język Polski 43 (1987): 45, 46. 
Sama klasa kaszubskich interiekcji była już przedmiotem zainteresowania badaczy - przede wszystkim orientowano się na opis wykrzykników adanimalnych oraz naśladujących dźwięki wydawane przez zwierzęta oraz ich reprezentacji w dziełach leksykograficznych oraz na tle kultury ludowej i sposobu postrzegania zwierząt przez społeczności lokalne - na Kaszubach wierzono bądź wierzy się nadal, iż niektóre zwierzęta dysponowały umiejętnością mówienia, ale została im ona odebrana za karę przez Boga. Największym zróżnicowaniem cechują się w gwarach kaszubskich interiekcje kierowane do gęsi i kur ${ }^{10}$.

Jak stwierdza L. Warda-Radys:

[...] głos zwierzęcia to monotonne powtarzanie tych samych dźwięków. Jest odbierany jako jedna sylaba z przedłużaną samogłoską (przede wszystkim ssaki) lub powtarzające się zgłoski (podobne lub różne). Problem leksykograficzny stanowi wyodrębnienie z przetworzonego przez człowieka ciągu dźwięków wydawanych przez zwierzę tego, co można by nazwać jednostką podstawową, stanowiącą pewną całość intonacyjną. Widać, że nie jest to zadanie łatwe. Na podstawie zebranego materiału wydaje się, że w dużej mierze ma to charakter subiektywny i intuicyjny (dlaczego zapisano beee, ale me; tak, ale tok tok i ko ko ko ko?). Oddawanie za pomocą określonego i ograniczonego systemu głosek danego języka dźwięków wydawanych przez zwierzęta prowadzi do tego, że człowiek zauważa pewne podobieństwo tych głosów do znaczących jednostek języka (swojego lub obcego) ${ }^{11}$.

Duma z lokalności, odrębności językowej, występowania czynników warunkujących spójność tożsamościową, integrujących świadomą kaszubską społecznośćc ${ }^{2}$, jest - jak się wydaje - właściwością uniwersalną, charakteryzującą wspólnoty lokalne o silnych tendencjach emancypacyjnych, opierających budowanie wzmiankowanej tożsamości na rzeczywistych czy jedynie wyobrażonych, czasem też projektowanych instytucjonalnie kryteriach wyjątkowości językowej. Tego typu przeświadczenie w codziennych, potocznych i swobodnych rozmowach z Kaszubami (po polsku) znajduje wyraz w metajęzykowych wypowiedziach, takich jak: „u nas tak się mówi/nie mówi”, „to nasze słowo, nie wasze, nie ich”, „to u nas, a nie u nich tak się mówi”, ,to słowo to oni od nas wzięli/ukradli od nas (sic!)” itd. Wydaje się jednak, że językowa świadomość swojskości interiekcji na poziomie dyskursu potocznego, zwykłej codziennej komunikacji tego typu uwarunkowaniom nie podlega. Inna sprawa, że kaszubszczyzna, mimo intensywnych zabiegów mających na celu doprowadzenie do końca procesu standaryzacji tego języka, ciągle jeszcze nie jest w pełni znormalizowana, o czym świadczą żywe polemiki choćby w obrębie gremium Rady Języka Kaszubskiego

\footnotetext{
10 Edward Breza, Jerzy Treder, Gramatyka kaszubska. Zarys popularny (Gdańsk: Zrzeszenie KaszubskoPomorskie, 1981).

11 Lucyna Warda-Radys, „Mowa zwierząt w Słowniku gwar kaszubskich Bernarda Sychty”, Acta Cassubiana 11 (2009): 155-165.

12 Szerzej na ten temat Monika Mazurek, „Czynniki wyznaczające tożsamość kaszubską: język, rodzina czy terytorium”, Acta Cassubiana 7 (2005): 25-36.
} 
(vide gramatyka autorstwa Hanny Makurat). W każdym razie interiekcje jawią się w tym miejscu jako pewna osobliwość leksykalna - albo w ogóle niepodlegająca standaryzacji, albo też znormalizowana bez jakichkolwiek obiektywnych przesłanek, w sposób niemal całkowicie przypadkowy, i nie jest to żadna lokalnie (tzn. w obrębie kaszubszczyzny) ograniczona tendencja.

W historycznym słowniku S. Ramulta z 1892 roku interiekcje opatrywane są oznaczeniem wykrz. (47 jednostek oraz ich warianty). Słownik pod względem reprezentacji materiału wykrzyknikowego można uznać za pożyteczniejszy od współczesnego dzieła Jana Trepczyka, gdyż leksykograf podaje tam ilustracje użyć wzmiankowanych jednostek, choć często bez opisu ich funkcji. W stosowaniu tego ostatniego rozwiązania autor nie jest jednak konsekwentny, pojawiają się bowiem w jego słowniku hasła zawierające wyłącznie domniemane ekwiwalenty polskie bądź - w przypadku interiekcji obcego pochodzenia - oryginalne ich postaci graficzne innojęzyczne (choć i od tej reguły zdarzają się wyjątki, np. adjé).

A, ACH, EH: A dosc mi ju tegò! A pudzesz! ACH Ach jak miã pchô w bòkù 'ach, jak mnie kłuje w boku'. Ach jaczé to pëszne rzeczë AJ aj, to belnô białka 'ach, to urodziwa kobieta' ALA Ala, knôpi! ‘hej, chłopcy’ Ala, bògu! 'przebóg, dla boga’ Ala, pse (a, do kata) Ala złémù (do licha) BIBI, luli, spij 'przy usypianiu dzieci' Bibi, żabinko, bibi, żużużu! Ob. biżu i żużu BIŻU, luli, spij. Biżu, sinku, bibibi. BUCH 'okrzyk na świnie’ (żywotność jednostki oraz jej geografię potwierdza monografia E. Siatkowskiej). Buchla, buch, buch! (buchla jako apelatyw w zn. 'świnia' - wyraz pieszczotliwy, rzeczownik odwykrzyknikowy). CZÓ! 'słysz, słuchaj, hej'. CZIP-CZIP 'woła się na kury': czip, czip, czipka, czip, czip, czip! (czipka 'kura') DIDLI! 'naśladowanie głosu skrzypiec podobnie jak dąm basów’ Didli, didli, dąm, dąm, jak pôn spiéwô, tak jô grôm [piosenka]. Ḋ̇AN-DŻAN! 'wykrzyknik w tańcu przy muzyce: hej-ha!' FIR-FIR! 'naśladowanie szelestu lotu ptaka' HA! 'ha, hej, aha, ach': Ha, môm cã! Ha, cëż môm robic! Ha, kòté, do robòté! HACZ, HACZKA! 'wykrzyknik celem popędzenia konia; wio': Hacz, séwô, hacz! > haczka 'nędzny koń, habeta' HE? 'wykrzyknik pytajny, co': Co të gôdôsz, he? HEJ! 'wykrz. hej!' HEJ-NO! 'wykrz. oto tam, hej tam' HELA, HELA! 'wykrzyknik przy popędzaniu gęsi' HI, HIJE! 'wykrzyknik na konie, wio' HISISI 'hej! wio! wykrz. na konie’ HÒ! ‘wykrz. òhò! ach!': Hò, co të so mëslisz?, Hò, tak! Hò, nie! HÒJA! ‘wykrz. hej! hola!': Hòja, chłopé, do robòtë! HOP! ‘wykrz., hop! hej!': Nie rzeczë rëchli hop, jaż przeskòczisz! HOT! ‘wykrz. na prawo!' IH ‘wykrz. eh! ba!': Ih, bò to prôwda! Ih, dejta, pòkój, sąsedze! ISA! ISKA! 'tak się woła na konie, aby przyszły’: Isa, iska, isisi! ISISI ‘wykrz. hej! wio! nuże!’ Tak woła się na konie. Ob. Iska JEJ! 'wykrz. 1) na trwogę! gwałtu! ratunku! na pomoc! 2) na wyrażenie podziwu, zdumienia: to dziwne! nie może być!’: Jej, lëdze, ratujta! Jej, jakòż to mòże bëc! JENCIE! 'wykrz. gwałtu! jej!' Jencie, co tù żëdów! Jencie, to të mnie chcesz zabic! JENË! 'biada! gwałtu! rety!': o, jenë, jene! Wò, jenë! JENKU! 'wykrz. ach! biada! gwałtu!': Jenku, ju pò nas! KSOB! 'wykrz. na lewo - woła się na konie, aby skręcały w lewo': Bjerzéta sã ksob! < ksob przysł. 'na lewo, po lewej stronie' MARSZ wykrz. 'marsz' Marsz do szkòłë! NA wykrz. 'na! masz! bierz!' NEŻ! wykrz. 'no! nuże! dalejże!’: Neż, 
do robòtë! NÔPRZÓD! wykrz. 'naprzód! marsz!' NIESTETË ‘niestety! biada!’: Ale niestetë nie bëło miãdzy namë nikògò, cobë sã rozmiôł na tëch rzeczach OHU! wykrz. 'ach! och! biada! gwałtu!': Ohu, ce ja pòcznã terô? OH! wykrz. 'och! ach!': Oh, jô neszczestlëwô! OJ! wykrz. 'oj, hej’: didididé - wykrzykuje się wesoło, jakby w takt muzyki; oj, biéda, biéda - okrzyk smutku PRECZ! wykrz. 'precz! won!': Idzié precz, të kòdrôku! Puj, puj! wykrz. 'okrzyk na kota, pol. kyci, kyci’ PYL, PYL; PY-LI-LI; PYLILI, PYLULU wykrz. 'W ten sposób przywołuje się gęsi' > pyla 'gęś' UHU! wykrz. 'wykrzyknik naśladujący głos puhacza’ WIÒ! wykrz. ‘o!, ach!’: Wò Jezë! Wò mój panie! WEJTALE! wykrz. 'patrzcie! o dziwo! hej!' WEJ! WEJ-LE! wykrz. 'oto, ot co': Wej, co za figle stroją!

Także u Ramułta widać wyraźną niekonsekwencję, jeśli chodzi o grafię interiekcji nie ma racjonalnego wytłumaczenia, dlaczego niektóre formy oparte na reiteracjach zapisywane są za pomocą dywizu, a inne z przecinkiem, inne jeszcze rozbite na dwie sylaby rozdzielone wykrzyknikiem (znakiem interpunkcyjnym). Ów znak nie stoi zresztą po każdej jednostce, którą Ramułt zakwalifikował jako interiekcję - nie wiadomo, czy jest to świadectwem jakiejś pogłębionej refleksji nad semantyką poszczególnych jednostek, jako tych, które wyraźnie wskazują na zintensyfikowanie siły głosu i odróżnienie takich form od wykrzykników „nie krzyczących”. W kwestii semantyki i pragmatyki odnotowanych interiekcji obserwujemy znaczną frekwencję wykrzykników dozwierzęcych, które u Trepczyka zaznaczone były marginalnie ( $p y l, p u j$, isisi, ksob, hacz, buch), emotywnych oraz onomatopeicznych.

W słowniku Jana Trepczyka z kolei zgodnie z przewidywaniami nie widać śladów podejmowania prób normalizacji graficznej interiekcji - panuje tutaj chaos i brak konsekwencji, szczególnie gdy chodzi o wykrzykniki wielokomponentowe albo oparte na reiteracjach (odnotowano tu ponad 60 jednostek oraz ich warianty). Ponadto w wielu przypadkach jednostki opatrzone oznaczeniem int $\mathrm{w}$ istocie są niebudzącymi wątpliwości co do możliwości ich zaklasyfikowania z punktu widzenia współczesnej wiedzy lingwistycznej partykułami. Przekładowy charakter słownika z polszczyzną jako językiem wyjściowym i kaszubszczyzną jako docelowym wymusił na autorze konieczność poszukiwania ekwiwalencji, co nastręczyło w praktyce wielu problemów - przy braku jednowyrazowych kaszubskich odpowiedników leksykograf musiał posiłkować się konstrukcjami analitycznymi o charakterze pełnych wypowiedzeń lub równoważników zdań.

Ach! int alaże!, a jenë (jo)!, ala!, ach!, o! aj! int ała!, ej!, aj! ale! ale! int le wej le! Ko gwës, le...!, në jo, le...!, hola! hola! Ba int në, në jo, në pewno, ko pewno, në ko pewno, bodôj, alasze, jesz bë co Basta! int dosc!, sygnie! basta! kùńc! Be int: ani be, ani me ani w tę, ani w nę; ani czóder, ani hójt czego aha! śmiechu ha, ha, ha! zaskoczenia, zakłopotania ala!, alasze! bólu ał! ała!, ostrzeżenia przed poparzeniem pch! ch! chë! hałasu ùbùdó!, ugryzienia, połknięcia ham! ham, ham! chciwości łaps! obrzydzenia ehë! rety! int w pòmoc!, na pòmòc! retënku! retëjta! bęc! int bół!, róbół!, 
buch!, rims!, czaps!, ùbùdó! biada! int urzas!, strach!; zwyciężonym! ùrzas dlô pòbitëch! strach dlô pòradzonëch! bis! int jesz rôz!, bis!, da capo! bòdaj(że) int wierę, bodôj(że); cię! brawo int ! brawo! brzdęk! int buch!, bums!, bół!, ùbùdó! buch! int bół!, bums!, buch! $\diamond$ buch w puch (mówia, idac do łóżka) cap! lap! int ùbùdó! rap, cap! chap! int łaps! chłaps! chlust! int chlust! cyt! int pst! czół! dalibóg int dôłëbóg, po prôwdze, dôlëszôk! ej(że)! int ej! $a$. hej! $a$. nële! fik! int hop! fiu fiu! int hejnë-wejnë!; jemu $\sim$ w głowie jemù sã cos mëkcy $a$. to je roztrãbarch fora! int precz!, rut(en)!; ze dwora! Le mie $\mathrm{z}$ widë! a. le sę karowac! gadu gadu int $\mathrm{w}$ bakowanim, w kôrbienim, w pérotanim; a my o dawnych czasach a më w bakowanim ò przódë czasach $\diamond$ gadu gadu, a knôpi na slëwach $a$. psë w krëpach hajda! int hajdu, nële tej! marsz! halo! int halo! halt int stojë! stojec! stój! hej! int hej! hola! hoc! int hop, hopa, hocka! hola! int hola!, hej! hokus-pokus $m$ hokus-pokus $a$. szacher-macher $m$ hop! hop! int hop! hop! hopsa(sa)! int hops!, hopsa(sa)! hosanna! int hos(j)anna!, sława! hura! int hura! huzia! int ùbùdó!, hucz! hyc! int hop(la)! jak to int jak to! jakuż! kaput! int kùńc! stracony, wszëtczëch kùńców kùńc kùkù! int kùkók! lap! int złap! chwatôj! chwëcë! lap-cap! int rap-cap! łupu! cupu! int ùbudó! niestety! int bòdôj!, (le) pòj sa (na)! Le wej! no! int në!, nële!, tej le!, nëże!, nëczkôjle!, nëtale!; dalej! në tej le!, nële tej! nu! int në, nëże! nuże! int nële!, nëże!, nëce le!, nëta le!, nëtaże! och! int ach!, och!, ała! ojej! int ùjna, ò jenë, jenkù! olaboga! int pot ùjna!, alaże! (w USJP jako przestarz.) pac! int bó! paf! int bó! pfe! int fùj!, ecz!, ehe!, fikak! puk, puk int bół, bół! rety! int w pòmòc!, na pòmòc! retënkù! retëjta! sza! int cëcho!, ps!, czó! wara! int precz od te(go) $a$. jô ce strzégóm! le mie biôj! wio! int hije! hija! wiwat! int wiwat! dobëcé! zdar! won! int precz! karuj sę! biôj rut! Biôj mie z widu! wyczha! int wësjë! ksjë! hësjë! WYCZHA (jednostka odnotowana w SJPD bez kwalifikatora, podana za SWil z cytatem z Pana Tadeusza: 'okrzyk zachęcający psy do rzucenia się na zwierzynę' [Wojski w Panu Tadeuszu] weź! int wez! wezkôj! na! na le! najkôj! naczkôj! weź go! (szczucie) ks! ksjë! hësjë! wësjë! hësgò! fësz! wio! int hije! hija!

Jako interiekcje oznaczane są tutaj zarówno rzeczywiste wykrzykniki (tzn. jednostki spełniające warunki zdefiniowane wcześniej), jak i partykuły, konstrukcje składniowe czy formy imperatywne. Dla wielu wyjściowych jednostek polskich nie udało się Trepczykowi odnaleźć pełnych ekwiwalentów kaszubskich, w innych sytuacjach okazywało się, że możliwe jest odnalezienie nawet kilku odpowiedników rodzimych (np. wësjë! ksjë! hësjë! dla wyjściowego wspomnianego wyczha). W kwestii typologii jednostek zwraca uwagę skąpa reprezentacja wykrzykników adanimalnych (w porównaniu z Sychtą i Ramułtem), a także dominacja interiekcji emotywnych oraz dźwięko- i ruchonaśladowczych.

W najważniejszym z kaszubskich kompendiów leksykograficznych, słowniku Bernarda Sychty, odnajdujemy z kolei olbrzymią liczbę jednostek interiekcyjnych, niezwykle zróżnicowanych zarówno pod względem formy, jak i funkcji, semantyki, pragmatyki i pochodzenia. Na potrzeby niniejszego szkicu wyekscerpowano $\mathbf{7 8}$ takich jednostek oraz ich warianty. W zbiorze tego leksykografa występują wykrzykniki (oznaczone w słowniku jako interj. albo tej informacji pozbawione), w porównaniu z innymi słownikami (również 
polskimi) są one opatrzone znacznie bardziej rozbudowanymi definicjami, które, oprócz podstawowych funkcji semantycznych jednostek, wskazują niekiedy także na ich wartość pragmatyczną oraz rolę pełnioną w tradycji i kulturze kaszubskiej; autor sygnalizuje również za pomocą kwalifikatorów ich recesywność lub niską frekwencję oraz lokalizację geograficzną. Odnotowane interiekcje pod względem budowy stanowią jednostki zarówno proste, jak i reiterowane, zbudowane z sylab lub morfemów (w takiej postaci są umieszczane jako wyrażenia hasłowe, i tak jak w przypadku pozostałych ekscerpowanych słowników brak tu spójności i konsekwencji zapisu ${ }^{13}$ ), derywaty słowotwórcze (w tym formacje deminutywne budowane na podstawach interiekcyjnych, także formacje oparte na konstrukcjach składniowych) i derywaty semantyczne.

ŁUP, ŁUP, ŁUP 'naśladowanie kroków i głosu upiora, zwanego Łupi' (chronologiczny kwalifikator nieliterowy w postaci krzyżyka, z lokalizacją na pd. zach. Kaszub); MAC 'wabienie kóz i królików’: mac, mac, mac! Por. kociewskie mać MARICZNIM! interj. 'wykrzyknik wyrażający zdziwienie, zwykle w połączeniu z innym słowem': A maricznim, Józkù, cëż to terô bãdze! A maricznim slicznim! MATIZERNOGA! matizer i noga! interj. 'wykrzyknik wyrażający zdziwienie, przestrach lub wzruszenie': A matizer i noga, co sã nie dzeje! [interiekcja o wyraźnie eufemistycznym charakterze, pozwalająca uniknąć użycia wykrzyknika blasfemicznego]. MËK! interj. 'wykrzyknik oznaczający nagłe zniknięcie’: Mëk, ju go nie bëło! MËR! MËR! interj. 1. 'naśladowanie głosu zmory’, 2. 'naśladowanie turkotu kołowrotka do przędzenia': Mora mrëczi, kej òna dëszi. Kółko robi mër! mër! MUK! interj. 'cicho!': Cëcho, ani muk! Ani muk nie rzek. CUDU MUDU 'wyraz zachodzący tylko w przysłowiu': Cudu-mudu, ò weselù ani dudu. NA! na le! interj. 'weź' NACZKÔJ! interj. dem od na 'weź': naczkôj le, nie wstidz sã! NË! NËLE! interj. 'no dalej!': në, le ju skòńcz! N’ËTALE! interj. 'zwrot wyrażający zdziwienie, zaskoczenie, niespodziankę, skierowany zazwyczaj do więcej osób, nawet nieobecnych; słuchajcie no, patrzcie no': n’ëtale dzatki, dzeż wa jesta, przińdzëta le tu! [W tym przypadku w samej definicji zawiera się przeświadczenie Sychty o pewnej - w jego mniemaniu - właściwości wykrzykników, tzn. takiego ich użycia, które jest zdeterminowane sytuacją komunikacyjną, wymagającą określonej formy kontaktu i konkretnego odbiorcy - M.K.]. NÓLE! interj. 'wyraz o charakterze ekspresywnym, używany jako wzmocnienie tybu rozkazującego lub w zastępstwie okrzyku ponaglającego, skierowany do jednej osoby lub jednego zwierzęcia: no, dalej, nuże!’: nóle, pódzesz të, bãdzesz mie sã zalécôł! nóle, chcesz mieć w pësk? N’ÓTALE! interj. 'wyraz skierowany do większej ilości osób lub zwierząt': n'ótale, mòje koniki! n'ótale, pospéwôjta sã, bo bãdze wnet wieczór! N’ÓCELE interj. 'zwrot grzecznościowy, skierowany do jednej, starszej osoby: pozwólcie, bądźcie tak uprzejmi’: n’ócele, jô wamô pòmogã zadwignąć ten miech. N'ÓTAŻE interj. 'wyraz skierowany do większej ilości ludzi lub zwierząt': n’ótaże, obérzeta te spadłé jabłka! NÓŻE interj. 'wyraz skierowany do

13 Bywa, że grafia wyrazów hasłowych (użycie dywizu lub spacji w zapisie interiekcji polisegmentalnych) jest odmienna niż ta, którą autor podaje w ilustracjach kontekstowych. 
jednej osoby lub zwierzęcia': Nóże, zagrzôj mie mleka! AHA! interj. 'wykrzyknik wyrażający przypomnienie, zadowolenie': Aha, terô jô jem doma! 'wiem już, o co chodzi'; Aha! Dobrzé, że milicjô tégò złodzeja złapała. ALUSZKU! interj. 'wykrzyknik wyrażający zachwyt lub pożałowanie dziecka’: Aluszku! Naszé dzecilko sã uderzëło, nie płaczkô le! ALUSZECZKU! interj. dem. od aluszku: aluszeczku! Mòże nasz sink vësoczkò spiéwkac. ACZ'I! APCZ'I! odm. apczi’ch (pd.) ‘wyraz naśladujący kichanie’: apcz'i! Boże dôj zdrowié! Zróbkôjle jesz rôz aczi (pn.). BAC!\# interj. 'wykrzyknik naśladujący upadnięcie dziecka': Bãdzesz tak długo biegôł, sinku, jaż të zrobisz bac. BAM! interj. 'wykrzyknik naśladujący upadek dziecka': Jena, chtëż to zrobił bam! BRR! interj. 'okrzyk wydawany w chwilach uczucia zimna, odrazy, pogardy, strachu': Brr, je tu zëmno BZ 'wyraz oznaczający, że ktoś jest niespełna rozumu’: Môsz të bz?! - tu w użyciu rzeczownikowym. BZZZ interj. 'odgłos szybkiego ruchu skrzydeł owadów, lecącej kuli itp.’: Ni móg jem usnąc, bo te muchi wkół mojë głowë leno bzzz... bzzz. CIMCIRIMCIM 'naśladowanie szmeru podczas oddawania moczu przez mężczyznę’: Kiedë chłop na bok ùstąpi, tedë to robi tak - cimcirimcim, cimcirimcim - a kiedë baba, to òna leje, jakbë sã chmura òberwała, z krzyżykiem CIP, CAP 'naśladowanie odgłosów młócących cepów' FUJ! interj. 'wykrzyknik wyrażający wstręt, obrzydzenie, naganę’: Fuj, posromôjże sã! FULMA 'wyraz zachodzący w przekleństwie': Żebë ce fulma kopa djôbłów wzãła! FUR! interj. 'wykrzyknik oznaczający nagłe zniknięcie': Fur! I go nie bëło... GLIN, GLIN onom. 'wyraz naśladujący dźwięk dzwonka’: W domie rozlég sã zwónk glin, glin, i gwiôzdka HAJDA! interj. 'wykrzyknik oznaczający nagłe zniknięcie, uciekanie': Wzął nogi za pas i hajda rwôł dodóm, le sã za nim kurzëło. HAM! oraz hamham! hem! oraz hemhem! 'wyraz w języku dzieci naśladujący jedzenie; używając go, poruszają ustami’: Zróbkôj le hamham! HEJ RUP! interj. 'wykrzyknik zachęcający do równoczesnego wykonania czynności wspólnymi siłami’ HOTATA! interj. 'wykrzyknik używany podczas podrzucania dzieci na kolanie, naśladujący jazdę konia' HURA! obok ura! interj. 'okrzyk wyrażający radość, uznanie, wiwaty’: Hura, më wëgralë! CHRUP-CHRUP onom. 'wyraz naśladujący odgłos, jaki powstaje w trakcie gryzienia czegoś chrupkiego': Nasz Stach ledwie wstôł i òn chrup-chrup skórkã chleba. IJ! interj. 'wykrzyknik wyrażający niedowierzanie': Ij, na swiecec bòskim, cëż të òpòwiôdôsz! Ij nie, jaż mie sã wierzëc nie chce, żebë to bëła prôwda. JENËSKA! JENËSKU! JENËSKUJKU! interj. 'wykrzyknik wyrażający przerażenie': Jenësku, cëż sã nie dzeje! Jenëskujku, jô sã przelãkła! Por. jenã, jena, jeny, jenku JENËSEJÃ! interj. 'wykrzyknik wyrażający przerażenie, podziw' JUCH CZUCH CZUCH! interj. 'okrzyk radości i szczęścia, szczególnie podczas tańca’: Parobk przëcësnął dzewczã do se i głosno krziknął: juch czuch czuch, Marjanko! KÃDË! interj. 'zwykle w połączeniu z wykrzyknikiem ala - wyraża zdziwienie’: Ala kãdë, kiejże ta urosła, dzéwczã! KILË! KILË! KILIKILI! ‘wyraz używany podczas łechtania': Móm cë zrobic kilikili, dzeż të môsz swòją nóżkã? KLAP! interj. 'wykrzyknik naśladujący dźwięk młócących cepów' (KLIP - odnotowane w tym samym zn., ale zbudowano wokół niego odrębne hasło) KNËKS interj. 'wyraz naśladujący pęknięcie': Te żarówki nie są nic wôrt - òne le zrobią knëks i są przepôloné. KÙLINKU! interj. 'wyraża 
zdziwienie, zwykle w połączeniu z wykrzyknikiem ala'. KÙRDËBELË! interj. Wejh. sporadycznie ‘okrzyk zdziwienia': Kurdëbelë! Tegò jem sã jednak nie spòdzôł. MORË’NOWIE! interj. zwykle w wyrażeniu daj go morë'nowie! 'wykrzyknik wyrażający podziw, zadowolenie': Daj go morë’nowie, kùpił të so konia! MIA, MIA ‘w języku dzieci: mięso' NAJKÔJLE! interj. 'weź’: najkôjle, dzecko, jabłuszko! NËŻE! interj. 'wyraz przynaglający, skierowany do jednej osoby' NËTAŻE! interj. 'wyraz przynaglający, skierowany do większej liczby osób’: nëtaże, zdrzëcëta jesz dzis to sano z fórë! NËŻ’ËKÔJLE! interj. dem. od nëże: nëż’ëkôjle, chłopku, przëcësni sã përznã do ksążki, a nauczisz sã bëlno czëtac! NËŻ'ËCZKÔJLE! interj. dem. od nëż'ëkôjle! PACZ! interj. 1. 'wykrzyknik naśladujący upadnięcie', 2. 'naśladujący klapsa' PLUMPS! onomat. 'naśladowanie wpadnięcia do wody, błota': Plumps! I òn bëł w wodze. PRÓST! interj. 'wykrzyknik zachęcający do picia jakiegokolwiek napoju alkoholowego’: Próst, na zdrowie młodé pôrë! Słownik etymologiczny kaszubszczyzny podaje ten wyraz w zn. 'prosię' od prsł. *pors-bcb. PUT, PUT 'w języku dzieci: naśladowanie oddawania wiatrów lub robienia kupki’: Chtëż to zrobił put, put? O, RÉTETA! interj. 'okrzyk wyrażający przerażenie' RUTUTU! onom. 'wyraz występujący w kołysankach i naśladujący dźwięk kolebki': Rutututu deska, mniała baba pieska...' SI! obok SIN! interj. 'wykrzyknik wyrażający podziw, zdziwienie, połączony z rozkaźnikiem daj'. SKL'ÓNOWIE! interj. 'wykrzyknik wyrażający zdziwienie, połączony najczęściej z jakimś innym wyrazem': Ala skl’ónowie! SZLÓP, SZLÓP onom. 'wyraz naśladujący powłóczysty chód' SZNËK'UT! interj. 'naśladowanie czkawki': Nasze dzecko robi sznëk'ut. SZRUP-SZRUP! interj. 'wyraz naśladujący odgłos powstający podczas rżnięcia sieczki' TIDIRIDILALA, TIDIRIDIRALALA! interj. 'okrzyk wydawany podczas śpiewania piosenki ludowej' TRA RA RA 'naśladowanie głosu skrzypiec w przyśpiewce tanecznej': Na skrzëpeczkach tra ra ra, poj do tuńca Barbara. TRALALA interj. 'przyśpiew podczas śpiewania piosenek, zwłaszcza gdy nie pamięta się tekstu’ (brak tej jednostki w USJP i WSJP, notuje ją SJPD), UR-UR onom. 'wyrazy naśladujące zgiełk, kłótnię, hałas': Ti nie mògą jinaczé ze sobą pògadac jak ur-ur. ÙTNOWIE! interj. 'zwykle w połączeniu z wykrzyknikiem ala, wyraża zdziwienie' VEJLENO! VEJNO! interj. 'wyraz kierujący uwagę na kogo lub co': Vejleno, tak të pòwinien to zrobic! Vejno, co mie sã stało! VEJKÔJ! interj. dem. od vej 'patrz oto': Vejkôj, jak të sã òczapôł, uważôj sinkù! V’EJTALE! interj. 'wyraz wyrażający zdziwienie, podziw, skierowany zwykle do większej ilości osób: o dziwo, patrzcie no': Vejtale, vejtale, weselé jedze! [w tym przypadku można wyodrębnić strukturę morfemową interiekcji, która prymarnie stanowiła połączenie formy werbalnej z partykułą]. VEJCZKÔJLE! interj. dem. od vejkôle VEJCELE interj. 'wyraz kierujący uwagę jednej starszej osoby': Vejcele, co jem kupiła sobie do sëkni! VEJ interj. 'wyraz kierujący uwagę na kogo lub co: patrz oto': Vej, jak te dzecë sã bawią! VEJLE - ten sam wyraz wzmocniony partykułą le.

Liczba interiekcji odnotowanych, opisanych i opatrzonych stosownymi ilustracjami użyć u Sychty zdecydowanie przewyższa ich reprezentację u pozostałych kaszubskich leksykografów. Uznanie budzi też konsekwentny opis, uwzględnianie wariantów graficznych, 
fonetycznych i morfologicznych takich jednostek oraz podjęcie (nie zawsze pomyślnie zakończonych) prób kwalifikowania wyrazów onomatopeicznych wśród szerszej klasy wykrzykników; z drugiej strony brak w tym wybitnym dziele kaszubskiej leksykografii informacji etymologicznej obok wykrzykników zapożyczonych. Interiekcje w dziele Sychty reprezentowane są przez jednostki niezwykle zróżnicowane zarówno pod względem funkcji, jak i pragmatyki. Ten drugi aspekt jest szczególnie ważny, gdy przyjrzeć się leksykograficznemu opisowi wykrzykników, takich jak n'ëtale, nóle, n'ótale, n'ócele, v'ejtale, vejcele, które w swej strukturze semantycznej zawierają informację o liczbie i niekiedy wieku adresatów, do których dana interiekcja jest kierowana - owa właściwość stanowi istotną cechę wykrzykników kaszubskich i wskazuje na ich zasadniczą odrębność w stosunku do podobnych zawołań w języku polskim. Bardzo licznie zaświadczone są w materiale onomatopeje (ur-ur, tidiridilala, tralala; szlóp, szlóp), w tym jednostki nieznane polszczyźnie współczesnej oraz historycznej (np. szlóp, szlóp, sznëk'ut!, glin, glin, cimcirimcim, cip, cap) oraz onomatopeje adresowane do dzieci lub pochodzące z ich mowy (aluszku, put, put; rututu, mia, mia). Jeśli chodzi o te kaszubskie interiekcje, których rodowód wywodził się z folkloru i swoistej mitologii regionalnej, pewną grupę o wspólnej genezie stanowią interiekcje quasi-onomatopeiczne, odnoszące się do wyobrażenia dźwięków wydawanych przez fantastyczne potwory czy istoty nadprzyrodzone. Osobną kwestią wartą rozważenia jest potencjał interiekcji jako bazy derywacyjnej - w materiale kaszubskim bardzo wyraźnie dostrzec można tendencję do budowania derywatów w oparciu o podstawy wykrzyknikowe - są to zarówno formacje rzeczownikowe, jak i werbalne oraz wśród nich także deminutywa (również drugiego stopnia, w obrębie klasy interiekcji infantalnych i adinfantalnych), np. aluszeczku, nëz'ëkôjle, nëz'ëczkôjle, naczkôj, jenëskujku. Owa deminutywizacja znajduje odzwierciedlenie w ich opisie leksykograficznym u Sychty.

Podsumowując, stwierdzić można, iż kaszubskie interiekcje wypełniają następujące zbiory:

A. mające tradycję względnie ciągłą, zaświadczone także w polszczyźnie historycznej i/lub współczesnej, mające postać formalną oraz funkcje tożsame z interiekcjami polskimi;

B. mające tradycję względnie ciągłą, zaświadczone także w polszczyźnie historycznej i/lub współczesnej, mające funkcje tożsame z interiekcjami polskimi, ale zmienioną postać formalną;

C. zaświadczone w polszczyźnie historycznej i/lub współczesnej, mające taki sam bądź zbliżony kształt formalny do jednostek polskich, ale odmienne od nich funkcje;

D. całkowicie odrębne pod względem formy i funkcji;

E. całkowicie odrębne, zawierające dodatkowy sem wskazujący na właściwości pragmatyczne. 

A. ach! basta! ata! ha! brawo! buch! hop! he? brr! tralalala
B. kilë! kilë! + kilikili! ùbudó! rap, cap! jencie! jenku! um-um! hej rup! kilë! kilë! kili- kili! pacz!'ò, réteta! acz'i! apcz'i! odm. apczi'ch
C. hola 'hej', hajda! klap! kurdëbelë!
D.juch czuch czuch! hucz! didli! aluszku! cimcirimcim; cip, cap; glin, glin; kulinku! rututu! si! skl'ónowie! szrup-szrup!
E. vejcele! n’ëtale! n’ótale! nóle! n’ócele! nóże! nëże! nëże! próst! v'ejtale! vejcele! n'ótaże.

Interiekcje w języku kaszubskim pod względem pełnionej funkcji można podzielić, uwzględniając kryteria klasyfikacyjne różnego typu (semantyczne, pragmatyczne, syntaktyczne, genetyczne) stosowane do tej pory na gruncie lingwistyki. Materiał pozwala wyodrębnić następujące grupy:

- onomatopeiczne (imitatywne): rututu! szlóp, szlóp, sznëk'ut! szrup-szrup! fur! plumps!

- adanimalne: $p y l, p u j, h a c z$

- adinfantalne (ad infantibus): hotata! kilë! kilë! aluszku! aluszeczku! bac! hotata!

- infantalne (de infantum): mia, mia, put, put, hamham

- emotywne (ekspresywne): brr! bz, fuj! jenëska!

- modalne (nakaźniki - termin za J. Strutyńskim): próst! vejleno! vejno! vejcele!

Pod względem budowy fonologicznej i morfemicznej dominują tu interiekcje wielokomponentowe i oparte na reiteracjach: właśnie w tym miejscu zarysowuje się istotna różnica między kaszubszczyzną a stanem współczesnym klasy wykrzykników w języku polskim, rosyjskim i serbsko-chorwackim, opisanym przez S. Daković:

Analiza fonologicznej struktury interiekcji również wykazuje wiele podobieństw w języku polskim, serbskim, chorwackim oraz rosyjskim. Nie bez znaczenia jest też to, że we wszystkich językach większość interiekcji jest jednosylabowa. Fakt ten podkreśla różnice między interiekcjami a resztą słownictwa. Świadczy również o specyficznym charakterze przekazu interiekcji, wyrażających treści zwięźle i ekspresywnie - forma przystosowana jest do pełnionych funkcji ${ }^{14}$.

Pod względem standardu opisu leksykograficznego interiekcje kaszubskie odnotowane w dziełach Ramułta, Sychty oraz Trepczyka wykazują podobieństwo do rozwiązań obecnych w historycznych, średnio- i nowopolskich słownikach przekładowych polszczyzny. W tym aspekcie klasa kaszubskich wykrzykników cechuje się brakiem standaryzacji graficznej (ta sama interiekcja zapisana w różny sposób w kilku źródłach słownikowych), znaczną dowolnością pod względem zapisu (forma syntetyczna, reiterowana, zapisana z przecinkiem lub dywizem/półpauzą), niekonsekwentnym kwalifikowaniem określonych

14 Daković, Interiekcje w języku polskim, 169. 
jednostek jako interiekcji albo przydawaniu w opisie leksykograficznym walorów interiekcji wyrazom reprezentującym inne części mowy. W porównaniu z historycznymi słownikami polszczyzny zarysowują się tu dwie istotne różnice: po pierwsze w ekscerpowanym materiale kaszubskim brak interiekcji łowieckich, jakże znamiennych dla dawnej polszczyzny w świetle kultury myśliwskiej Rzeczypospolitej; po drugie, pozostałe interiekcje są dość konsekwentnie wyodrębniane za pomocą charakterystycznego oznaczenia interj., a także z wykrzyknikami nie są już utożsamiane niektóre formy wokatywu oraz imperatywu, co zaobserwować było można, przeszukując XVII- i XVIII-wieczne źródła polskie. Niektóre z notowanych u Sychty interiekcji są bezpośrednimi cytatami z piosenek, przyśpiewek i zabaw ludowych - te jawią się jako szczególnie ważne świadectwa kultury duchowej Kaszub.

Nawet ten dość pobieżny przegląd materiału interiekcyjnego, wyekscerpowanego z trzech źródeł słownikowych, pokazuje, iż ta klasa słownictwa, która zazwyczaj w słownikach języka ogólnego reprezentuje pewnie margines (a i metody jej definiowania budzą poważne zastrzeżenia, na co zwracają uwagę językoznawcy), zajmuje w kaszubskiej świadomości lingwistycznej wyjątkowe miejsce: szczególnie widoczne jest to w pomnikowym dziele B. Sychty, gdzie znamienna jest nie tylko liczba takich jednostek, ale też konsekwentne ilustrowanie ich użycia za pomocą kolokacji. Zbiór kaszubskich wykrzykników (szczególnie tych, które odnotowano w ostatnim z ekscerpowanych źródeł) z całą pewnością zasługuje na rzetelne i kompleksowe opracowanie - obiecującą perspektywą wydają się tu badania kontrastywne, które przyniosły wymierne efekty w pracach choćby E. Orwińskiej-Ruziczki czy S. Daković.

\section{Bibliografia}

\section{Źródla}

Ramułt, Stefan. Słownik języka kaszubskiego, czyli pomorskiego. Kraków: Wydawnictwo Akademii Umiejętności, 1893.

Sychta, Bernard. Słownik gwar kaszubskich. Wrocław: Komitet Językoznawstwa Polskiej Akademii Nauk. Gdańskie Towarzystwo Naukowe, 1967 (T. 1); Wrocław 1968 (T. 2); Wrocław 1969 (T. 3); Wrocław 1970 (T. 4); Wrocław 1972 (T. 5); Wrocław 1973 (T. 6); Wrocław 1976 (T. 7 Suplement).

Trepczyk, Jan. Słownik polsko-kaszubski, oprac. Jerzy Treder. T. 1-2. Gdańsk: Zrzeszenie KaszubskoPomorskie, 1994.

Breza, Edward, Jerzy Treder. Gramatyka kaszubska. Zarys popularny. Gdańsk: Zrzeszenie KaszubskoPomorskie, 1981.

Daković, Sybilla. „Interiekcje onomatopeiczne w języku polskim, serbskim, chorwackim i rosyjskim”. W: VARIA XV. Zborník materiálov z XV. kolokvia mladých jazykovedcov (Banská Bystrica-Tajov 7-9. 2005), red. Alexandra Gálisová, Anna Chomová. Bratislava: Slovenská jazykovedná spoločnost' pri SAV, 2008. 
Daković, Sybilla. Interiekcje w języku polskim, serbskim, chorwackim i rosyjskim. Opis i konfrontacja. Wrocław: Wydawnictwo Uniwersytetu Wrocławskiego, 2006.

Daković, Sybilla. „Onomatopeje i wykrzykniki w języku polskim i serbsko-chorwackim”. W: Wyraz i zdanie w językach słowiańskich. Opis, konfrontacja, przekład, 4, red. Larysa Pisarek, Jan Sokołowski, 145-151. Wrocław: Wydawnictwo Uniwersytetu Wrocławskiego, 2000.

Daković, Sybilla. „Semantyka interiekcji słowiańskich (w języku polskim, serbskim/chorwackim i rosyjskim)". W: Wyraz i zdanie w językach stowiańskich. Opis, konfrontacja, przekład, 5, red. Michał Sarnowski, Włodzimierz Wysoczański, 81-87. Wrocław: Wydawnictwo Uniwersytetu Wrocławskiego, 2005.

Grochowski, Maciej. „O miejscu interiekcji w systemie gramatycznym języka (na przykładzie współczesnego języka polskiego)". Prilozi 12 (1987), 2: 51-59.

Grochowski, Maciej. „Pojęcie jednostki funkcyjnej. Z historii metodologii składni polskiej”. W: Wyrażenia funkcyjne w perspektywie diachronicznej, synchronicznej i porównawczej, red. Krystyna Kleszczowa, Anna Szczepanek. Katowice: Wydawnictwo Uniwersytetu Śląskiego, 2014.

Grochowski, Maciej. „Status semantyczny wykrzykników właściwych”. Prace Filologiczne 37 (1992): 155-163.

Grochowski, Maciej. „Wprowadzenie do analizy syntaktycznej wykrzykników”. Polonica 13 (1989): $85-100$.

Grochowski, Maciej. Wyrażenia funkcyjne. Studium leksykograficzne. Kraków: Wydawnictwo Instytutu Języka Polskiego PAN, 1997.

Kaszewski, Marek. „Interiekcje w dawnych przekładowych słownikach języka polskiego”. W: Badania diachroniczne w Polsce II. Między współczesnościq a przeszłościa, red. Anna Krzyżanowska, Małgorzata Posturzyńska-Bosko, Piotr Sorbet. Lublin: Wydawnictwo UMCS, 2016.

Krzempek, Monika. „Kognitywna analiza semantyczna polskich wykrzykników”. Stylistyka 27 (2018): $117-134$.

Krzempek, Monika. „Miejsce wykrzyknika w systemie części mowy - wykrzyknik w ujęciu kognitywnym”. Prace Filologiczne 64 (2014), 2: 187-202.

Krzempek, Monika. „Semantyka czeskich wykrzykników”. Bohemistyka 15 (2015), 2: 103-125.

Mirowicz, Anatol. Przegląd i charakterystyka części mowy w języku rosyjskim. Warszawa: Państwowe Wydawnictwo Naukowe, 1967.

Orwińska-Ruziczka, Elżbieta. Funkcje językowe interiekcji w świetle materiału stowackiego i polskiego. Kraków: Universitas, 1992.

Popowska-Taborska, Hanna. „O Słowniku kaszubskim Bernarda Sychty”. Język Polski 43 (1963), 1-2: 99-101.

Popowska-Taborska, Hanna. Szkice z kaszubszczyzny. Gdańsk: Muzeum Piśmiennictwa i Muzyki Kaszubsko-Pomorskiej w Wejherowie i Towarzystwo Przyjaciół Ziemi Wejherowskiej, 1987.

Siatkowska, Ewa. „Słowiańskie wykrzykniki i partykuły od ględ- i ich homonimy”. Studia z Filologii Polskiej i Stowiańskiej 9 (1969): 271-278.

Siatkowska, Ewa. „Słowiańskie wyrazy pomocnicze i morfemy z elementem -d-”. Studia z Filologii Rosyjskiej i Stowiańskiej 5 (1984), 99-113.

Siatkowska, Ewa. „Wyrazy dźwiękonaśladowcze a wykrzykniki (studium porównawcze na materiale czeskim i polskim)". Poradnik Językowy 3 (1977): 99-105.

Siatkowska, Ewa. „Z morfologii tzw. wyrazów amorficznych w języku polskim i słowackim”. Studia z Filologii Polskiej i Słowiańskiej 23 (1985): 285-293.

Siatkowska, Ewa. Zachodniostowiańskie zawołania na zwierzęta. Warszawa: Wydawnictwo Uniwersytetu Warszawskiego, 1976.

Strutyński, Janusz. „Sposoby naśladowania głosów ptaków w języku polskim”. Zeszyty Naukowe Uniwersytetu Jagiellońskiego. Prace Językoznawcze 114 (1965), 15: 85-117. 
Styrcz-Przebinda, Leokadia. „Parę uwag o możliwościach klasyfikacji wykrzykników”. Polonica 18 (1997): 162-167.

Świątkowska, Marcelina. A może na początku był wykrzyknik? W: Między oryginatem a przekładem. Seria: Na poczatku byt przektad, red. Maria Filipowicz-Rudek, Jadwiga Konieczna-Twardzikowa, Urszula Kropiwiec, 277-286. T. 5. Kraków, 1999.

Świątkowska, Marcelina. Entre dire et faire. De l'interjection. Kraków: Wydawnictwo Uniwersytetu Jagiellońskiego, 2000.

Świątkowska, Marcelina. "L'interjection: entre deixis et metaphore”. Langages 161 (2006): 47-56.

Świątkowska, Marcelina. „Quelques considérations sur la nature de l'interjection”. Prace Językoznawcze 63 (1979): 49-62.

Warda-Radys, Lucyna. „Mowa zwierząt w Stowniku gwar kaszubskich Bernarda Sychty”. Acta Cassubiana 11 (2009): 155-165.

\section{O interiekcjach kaszubskich w perspektywie leksykograficznej}

\section{Streszczenie}

Przedmiotem szkicu jest status klasy interiekcji w języku kaszubskim, miejsce wykrzykników w świadomości lingwistycznej kaszubskich leksykografów, metody opisu tych jednostek w trzech źródłach słownikowych, ich zróżnicowanie oraz próba typologii.

\section{On Kashubian interjections from the lexicographical perspective}

\section{Sum mary}

The subject of this sketch is the status of the class of interjections in the Kashubian language, the role of interjections in the linguistic awareness of the Kashubian lexicographers, methods of defining these units in three dictionary sources, their characteristics, and an attempt at typology.

Cytowanie

Kaszewski, Marek. „O interiekcjach kaszubskich w perspektywie leksykograficznej”. Studia Językoznawcze. Synchroniczne i diachroniczne aspekty badań polszczyzny 19 (2020): 163-180. DOI: 10.18276/sj.2020.19-11. 